\title{
Dangerous exercise. The detrimental effects of exertion and orthostatic stress in Myalgic Encephalomyelitis and chronic fatigue syndrome
}

\author{
Frank NMTwisk ${ }^{* 1}$
}

${ }^{1}$ ME-de-patiënten Foundation, Limmen, the Netherlands

Exercise, especially regular exercise, is known to have various beneficial effects on the health status $[1,2]$. However when immunological, stress and other responses to physical activity are dysregulated, exercise can become detrimental to health [3].

Looking at the evidence so far, this latter observations seems also to be applicable to Myalgic Encephalomyelitis (ME) and chronic fatigue syndrome (CFS). Although ME and CFS are often declared to be synonyms [4], the diagnostic criteria define two distinct clinical entities. ME is primarily defined by muscle weakness (and myalgia) after a minor exertion lasting for days and characteristic neurological features, while CFS is primarily defined by (unexplained, incapacitating) chronic fatigue [4]. Although ME and CFS are to be considered to be two distinct, partially overlapping, diagnostic labels [4], the Institute of Medicine [5] confirmed that post-exertional "malaise", defined as a prolonged aggravation of typical symptoms (e.g. "brain fog"/ cognitive deficits and muscle and joint pain) is the hallmark feature of "ME/CFS".

Despite this methodologic hurdle, i.e. research into mixed ME and/ or CFS patient populations, various characteristic aberrations have been found repetitively. Exercise-related abnormalities [6] are associated with a) energetic abnormalities, which seem to be amplified by exertion, including mitochondrial dysfunction [7-10], (very) low oxygen uptake [11-13], reduced oxygen supply to muscles [14] and brain [15], and excessive acidosis and recovery from exercise-induced acid [13,16,17]; b) muscular abnormalities related to exercise [18-20]; c) increased pain sensitivity and lower pain threshold induced by exercise [21-23]; d) long-lasting oxidative stress in response to exercise [19,21,24]; e) cardiovascular abnormalities [25-27]; f) deviant autonomic responses to exertion and orthostatic stress [28-30]; g) neurological abnormalities in relation to exercise [31-33]; h) immunologic abnormalities after exertion [32,34,35]; i) exercise-induced gastro-intestinal abnormalities, including bacterial translocation [36-38]; j) attenuated stress responses to exercise $[39,40]$; and $\mathrm{k}$ ) ion channel dysfunction during rest and in response to exercise [41-43]. These abnormalities can plausibly explain post-exertional "malaise" in ME/CFS [44].

Physical deconditioning is not a perpetuating factor in ME/CFS [45]. Deconditioning also cannot account for the aberrations observed, especially since various studies have used sedentary controls, e.g. $[11,13,46]$. Deconditioning also cannot explain the profound fall in exercise capacity (maximum oxygen uptake/workload and/or oxygen uptake/workload at the anaerobic threshold) at a second exercise test and the inability of ME/CFS patients to reproduce VO2peak 24 hours later [47-49].
Interestingly, recent studies observed a hypometabolic state [50,51], which was characterized by one study as 'dauer' [52]. Although male and female patients seem to compensate differently, these studies show 'inadequate ATP generation by oxidative phosphorylation and excessive lactate generation upon exertion' [53].

So, while the deconditioning hypothesis seems tempting, graded exercise protocols seem to have detrimental effects on many patients [54]. In the case of ME/CFS it is wise to acknowledge the potential dangers of exercise to avoid iatrogenic harm.

\section{References}

1. Walsh NP, Gleeson M, Shephard RJ, Gleeson M, Woods JA, et al. (2011) Position statement. Part one: Immune function and exercise. ExercImmunol Rev 17: 6-63. [Crossref]

2. Walsh NP, Gleeson M, Pyne DB, Nieman DC, Dhabhar FS, et al. (2011) Position statement. Part two: Maintaining immune health. ExercImmunol Rev 17: 64-103. [Crossref]

3. Cooper DM, Radom-Aizik S, Schwindt C, Zaldivar FJ (2007) Dangerous exercise: lessons learned from dysregulated inflammatory responses to physical activity. $J \mathrm{Appl}$ Physiol 103: 700-709. [Crossref]

4. Twisk FN (2014) The status of and future research into Myalgic Encephalomyelitis and chronic fatigue syndrome: the need of accurate diagnosis, objective assessment and acknowledging biological and clinical subgroups. Front Physiol 5: 109. [Crossref]

5. Institute of Medicine (2015) Beyond Myalgic Encephalomyelitis/chronic fatigue syndrome: redefining an illness. Washington, DC. ISBN: 978-0-309-31689-7.

6. Twisk FNM (2015) Prolonged abnormal effects of exercise in Myalgic Encephalomyelitis and chronic fatigue syndrome. J JPhysiother Exercise 1: 001.

7. Myhill S, Booth NE, McLaren-Howard J (2009) Chronic fatigue syndrome and mitochondrial dysfunction. Int J Clin Exp Med 2: 1-16.

8. Booth NE, Myhill S, McLaren-Howard J (2012) Mitochondrial dysfunction and the pathophysiology of myalgic encephalomyelitis/chronic fatigue syndrome (ME/CFS). Int J Clin Exp Med 5: 208-220. [Crossref]

9. Wong R, Lopaschuk G, Zhu G, Walker D, Catellier D, et al. (1992) Skeletal muscle metabolism in the chronic fatigue syndrome. In vivo assessment by $31 \mathrm{P}$ nuclear magnetic resonance spectroscopy. Chest 102: 1716-1722. [Crossref]

10. Kaushik N, Fear D, Richards SC, McDermott CR, Nuwaysir EF, et al. (2005) Gene expression in peripheral blood mononuclear cells from patients with chronic fatigue syndrome. J Clin Pathol 58: 826-832. [Crossref]

11. De Becker P, Roeykens J, Reynders M, McGregor N, De Meirleir K (2000) Exercise capacity in chronic fatigue syndrome. Arch Intern Med 160: 3270-3277. [Crossref]

Correspondence to: Frank NM Twisk, Zonnedauw 15, 1906 HB Limmen, The Netherlands, Tel. +31-72-5050 4775; E-mail: frank.twisk@hetnet.nl

Received: January 29, 2017; Accepted: February 23, 2017; Published: February 25,2017 
12. Ickmans K, Clarys P, Nijs J, Meeus M, Aerenhouts D, et al. (2013) Association between cognitive performance, physical fitness, and physical activity level in women with chronic fatigue syndrome. J Rehabil Res Dev 50: 795-810. [Crossref]

13. Jones DE, Hollingsworth KG, Jakovljevic DG, Fattakhova G, Pairman J, et al. (2012) Loss of capacity to recover from acidosis on repeat exercise in chronic fatigue syndrome: a case-control study. Eur J Clin Invest 42: 186-194.[Crossref]

14. Miller RR, Reid WD, Mattman A, Yamabayashi C, Steiner T, et al. (2015) Submaximal exercise testing with near-infrared spectroscopy in Myalgic Encephalomyelitis/chronic fatigue syndrome patients compared to healthy controls: a case-control study. J Trans Med 13: 159. [Crossref]

15. Patrick Neary J, Roberts AD, Leavins N, Harrison MF, Croll JC, et al. (2008) Prefrontal cortex oxygenation during incremental exercise in chronic fatigue syndrome. Clin Physiol Funct Imaging 28: 364-372. [Crossref]

16. Jones DE, Hollingsworth KG, Taylor R, Blamire AM, Newton JL (2010) Abnormalities in $\mathrm{pH}$ handling by peripheral muscle and potential regulation by the autonomic nervous system in chronic fatigue syndrome. J Intern Med 267: 394-401.[Crossref]

17. He J, Hollingsworth KG, Newton JL, Blamire AM (2013) Cerebral vascular control is associated with skeletal muscle $\mathrm{pH}$ in chronic fatigue syndrome patients both at rest and during dynamic stimulation. Neuroimage Clin 2: 168-173. [Crossref]

18. Brown AE, Jones DE, Walker M, Newton JL (2015) Abnormalities of AMPK activation and glucose uptake in cultured skeletal muscle cells from individuals with chronic fatigue syndrome. PLoS One 10: e122982. [Crossref]

19. Jammes Y, Steinberg JG, Delliaux S, Brégeon F (2009) Chronic fatigue syndrome combines increased exercise-induced oxidative stress and reduced cytokine and Hsp responses. J Intern Med 266: 196-206. [Crossref]

20. Paul L, Wood L, Behan WM, Maclaren WM (1999) Demonstration of delayed recovery from fatiguing exercise in chronic fatigue syndrome. Eur J Neurol 6: 63-69. [Crossref]

21. Vecchiet L, Montanari G, Pizzigallo E, Iezzi S, de Bigontina P, et al. (1996) Sensory characterization of somatic parietal tissues in humans with chronic fatigue syndrome. Neurosci Lett 208: 117-120. [Crossref]

22. Whiteside A, Hansen S, Chaudhuri A (2004) Exercise lowers pain threshold in chronic fatigue syndrome. Pain 109: 497-499.[Crossref]

23. Light AR, White AT, Hughen RW, Light KC (2009) Moderate exercise increases expression for sensory, adrenergic, and immune genes in chronic fatigue syndrome patients but not in normal subjects. J Pain 10: 1099-1112. [Crossref]

24. Fulle S, Mecocci P, Fanó G, Vecchiet I, Vecchini A, et al. (2000) Specific oxidative alterations in vastuslateralis muscle of patients with the diagnosis of chronic fatigue syndrome. Free RadicBiol Med 29: 1252-1259. [Crossref]

25. Hollingsworth KG1, Jones DE, Taylor R, Blamire AM, Newton JL (2010) Impaired cardiovascular response to standing in chronic fatigue syndrome. Eur J Clin Invest 40: 608-615.[Crossref]

26. Hurwitz BE, Coryell VT, Parker M, Martin P, Laperriere A, et al. (2009) Chronic fatigue syndrome: illness severity, sedentary lifestyle, blood volume and evidence of diminished cardiac function. Clin Sci (Lond) 118: 125-135. [Crossref]

27. Miwa K (2015) Cardiac dysfunction and orthostatic intolerance in patients with myalgic encephalomyelitis and a small left ventricle. Heart Vessels 30: 484-489. [Crossref]

28. Cordero DL, Sisto SA, Tapp WN, LaManca JJ, Pareja JG, et al. (1996) Decreased vagal power during treadmill walking in patients with chronic fatigue syndrome. Clin Auton Res 6: 329-333.[Crossref]

29. Wyller VB, Due R, Saul JP, Amlie JP, Thaulow E (2007) Usefulness of an abnormal cardiovascular response during low-grade head-up tilt-test for discriminating adolescents with chronic fatigue from healthy controls. Am J Cardiol 99: 997-1001. [Crossref]

30. Wyller VB, Saul JP, Walløe L, Thaulow E (2008) Sympathetic cardiovascular control during orthostatic stress and isometric exercise in adolescent chronic fatigue syndrome. Eur J Appl Physiol 102: 623-632. [Crossref]

31. Stewart JM, Medow MS, Messer ZR, Baugham IL, Terilli C, et al. (2012) Postural neurocognitive and neuronal activated cerebral blood flow deficits in young chronic fatigue syndrome patients with postural tachycardia syndrome. Am J Physiol Heart Circ Physiol 302(5): H1185-H1194.[Crossref]

32. Peterson PK, Sirr SA, Grammith FC, Schenck CH, Pheley AM, et al. (1994) Effects of mild exercise on cytokines and cerebral blood flow in chronic fatigue syndrome patients. Clin Diagn Lab Immunol 1: 222-226.[Crossref]
33. Blackwood SK, MacHale SM, Power MJ, Goodwin GM, Lawrie SM (1998) Effects of exercise on cognitive and motor function in chronic fatigue syndrome and depression. J Neurol Neurosurg Psychiatry 65: 541-546. [Crossref]

34. Sorensen B, Streib JE, Strand M, Make B, Giclas PC, et al. (2003) Complement activation in a model of chronic fatigue syndrome. J Allergy Clin Immunol 112: 397 403.[Crossref]

35. White PD, Nye KE, Pinching AJ, Yap TM, Power N, et al. (2004) Immunological changes after both exercise and activity in chronic fatigue syndrome: a pilot study. $J$ Chronic Fatigue Syndr 12: 51-66.

36. Shukla SK, Cook D, Meyer J, Vernon SD, Le T, et al. (2015) Changes in gut and plasma microbiome following exercise challenge in Myalgic Encephalomyelitis/ chronic fatigue syndrome (ME/CFS). PLoS One 10: e0145453. [Crossref]

37. Giloteaux L, Goodrich JK, Walters WA, Levine SM, Ley RE, et al. (2016) Reduced diversity and altered composition of the gut microbiome in individuals with myalgic encephalomyelitis/chronic fatigue syndrome. Microbiome 4: 30. [Crossref]

38. Giloteaux L, Hanson MR, Keller BA (2016) A pair of identical twins discordant for Myalgic Encephalomyelitis/chronic fatigue syndrome differ in physiological parameters and gut microbiome composition. Am J Case Rep 17: 720-729.[Crossref]

39. Thambirajah AA, Sleigh K, Stiver HG, Chow AW (2008) Differential heat shock protein responses to strenuous standardized exercise in chronic fatigue syndrome patients and matched healthy controls. Clin Invest Med 31: E319-E327. [Crossref]

40. Gaab J, Hüster D, Peisen R, Engert V, Heitz V, et al. (2002) Hypothalamic-pituitaryadrenal axis reactivity in chronic fatigue syndrome and health under psychological, physiological, and pharmacological stimulation. Psychosom Med 64: 951-962. [Crossref]

41. Broderick G, Craddock RC, Whistler T, Taylor R, Klimas N, et al. (2006) Identifying illness parameters in fatiguing syndromes using classical projection methods. Pharmacogenomics 7: 407-419. [Crossref]

42. Cameron B, Galbraith S, Zhang Y, Davenport T, Vollmer-Conna U, et al. (2007) Gene expression correlates of postinfective fatigue syndrome after infectious mononucleosis. J Infect Dis 196: 56-66. [Crossref]

43. Whistler T, Jones JF, Unger ER, Vernon SD (2005) Exercise responsive genes measured in peripheral blood of women with chronic fatigue syndrome and matched control subjects. BMC Physiol 5: 5. [Crossref]

44. Twisk FNM (2015) The 4I hypothesis: A neuro-immunological explanation for characteristic symptoms of Myalgic Encephalomyelitis/chronic fatigue syndrome. Int J of Neurol Res 1: 20-38.

45. Bazelmans E, Bleijenberg G, van der Meer JWM, Folgering H (2001) Is physical deconditioning a perpetuating factor in chronic fatigue syndrome? A controlled study on maximal exercise performance and relations with fatigue, impairment and physical activity. Psychol Med 31: 107-114. [Crossref]

46. Suárez A, Guillamo E, Roig T, Blázquez A, Alegre J, et al. (2010) Nitric oxide metabolite production during exercise in chronic fatigue syndrome: a case-control study. J Womens Health (Larchmt) 19(6): 1073-1077. [Crossref]

47. Keller BA, Pryor JL, Giloteaux L (2014) Inability of myalgic encephalomyelitis chronic fatigue syndrome patients to reproduce $\mathrm{VO} 2$ peak indicates functional impairment. J Transl Med 12: 104. [Crossref]

48. Snell CR, Stevens SR, Davenport TE, VanNess JM (2013) Discriminative validity of metabolic and workload measurements to identify individuals with chronic fatigue syndrome. Phys Ther 93: 1484-1492. [Crossref]

49. Vermeulen RCW, Kurk RM, Visser FC, Sluiter W, Scholte HR (2010) Patients with chronic fatigue syndrome performed worse than controls in a controlled repeated exercise study despite a normal oxidative phosphorylation capacity. J Transl Med 8: 93. [Crossref]

50. Yamano E, Sugimoto M, Hirayama A, Kume S, Yamato M, et al. (2016) Index markers of chronic fatigue syndrome with dysfunction of TCA and urea cycles. Sci Rep 6: 34990.[Crossref]

51. Germain A, Ruppert D, Levine SM, Hanson MR (2017) Metabolic profiling of a myalgic encephalomyelitis/chronic fatigue syndrome discovery cohort reveals disturbances in fatty acid and lipid metabolism. Mol Biosyst 13: 371-379. [Crossref]

52. Naviaux RK, Naviaux JC, Li K, Bright AT, Alaynick WA, et al. (2016) Metabolic features of chronic fatigue syndrome. Proc Natl Acad Sci U S A 113: E5472-5480. [Crossref] 
Twisk FMN (2017) Dangerous exercise. The detrimental effects of exertion and orthostatic stress in Myalgic Encephalomyelitis and chronic fatigue syndrome

53. Fluge Ø, Mella O, OveBruland O, Risa K, Dyrstad SE, et al. (2016) Metabolic profiling indicates impaired pyruvate dehydrogenase function in myalgic encephalopathy/ chronic fatigue syndrome. JCI Insight 1: e89376. [Crossref]
54. Twisk FNM, Maes M (2009) A review on cognitive behavorial therapy (CBT) and graded exercise therapy (GET) in myalgic encephalomyelitis (ME) / chronic fatigue syndrome (CFS): CBT/GET is not only ineffective and not evidence-based, but also potentially harmful for many patients. Neuro Endocrinol Lett 30: 284-299. [Crossref]

Copyright: (C2017 Twisk FMN. This is an open-access article distributed under the terms of the Creative Commons Attribution License, which permits unrestricted use, distribution, and reproduction in any medium, provided the original author and source are credited. 